\title{
Activity-Based Costing In Small Manufacturing Firms: South African Study
}

\author{
Rosebud Rundora, Vaal University of Technology, South Africa \\ Toekie Ziemerink, Vaal University of Technology, South Africa \\ Merwe Oberholzer, North-West University, Potchefstroom Campus, South Africa
}

\begin{abstract}
This is an empirical investigation by means of a survey of the experiences and perceptions of activity-based costing $(A B C)$, as an alternative to traditional costing, in small manufacturing firms in the Southern Gauteng region of South Africa. The objectives of the study were to determine the: Extent to which $A B C$ is adopted; Perceptions of the benefits and the barriers of $A B C$; Experiences regarding the practice of $A B C$; and Reasons why firms do not adopt $A B C$. An analysis of 48 questionnaires indicated that 16 firms implemented $A B C$ whilst 32 did not adopt this approach. The study firstly found that the $A B C$ users have been in business significantly longer than the non-users, ABC users' firms are significantly larger than the non-users firms', there are some significant differences in the perceptions between the users and non-users regarding the benefits and the barriers of implementing $A B C$, that the $A B C$ users are to a great extent neutral in respect of the practical issues of $A B C$ and finally, that the non-users of $A B C$ are of the opinion that $A B C$ is too expensive to implement. The contribution of this study is that it fills the gap regarding to the lack of empirical research of $A B C$ in small manufacturing firms and especially the lack of empirical research on $A B C$ in South African firms.
\end{abstract}

Keywords: Small Manufacturing Firms; Activity-Based Costing (ABC); Traditional Costing

\section{INTRODUCTION}

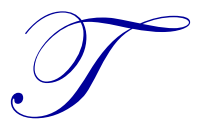

his study is an empirical investigation by means of a survey of the experiences and perceptions of activity-based costing $(\mathrm{ABC})$, as an alternative to traditional costing, in small manufacturing firms in South Africa. $\mathrm{ABC}$ has been a critical research area that has drawn considerable attention from academics and practitioners, e.g. Zhang and Che (2011), Liu and Gong (2011), Khataie et al. (2011), Sartorius et al. (2007), Thyssen et al. (2006), Robinson-Backmon (2004), Gupta and Galloway (2003), Oberholzer and Van Zyl (2000), Cooper and Slagmulder (1999), Gunasekaran and Singh (1999), Raz and Elnathan (1999), Yahya-Zadeh (1998) and Cooper and Kaplan (1991). The review of literature and current research seems to indicate that firms often neglect cost accounting methods and use methods that are no longer relevant to the changing manufacturing environment (Atrill \& McLaney, 2007). Although considerable progress has been made in implementing new cost accounting techniques (Drury, 2011), and despite the many strides the accounting profession has made over the years, ABC practices have not taken as strong a hold in firms as they should have (Mersereau, 2007). Since its introduction in the 1980s, the implementation of $\mathrm{ABC}$ has grown rapidly in large manufacturing companies, but less frequent is the development and implementation in small manufacturing companies (Needy et al., 2003; Gunasekaran \& Singh, 1999). The importance of this study is that small business owners and managers can better understand the firms' profiles that implemented $\mathrm{ABC}$, the benefits, barriers and practical issues of $\mathrm{ABC}$ as well as reasons why firms prefer not to adopt $\mathrm{ABC}$.

The problem identified by this study is that $\mathrm{ABC}$ is investigated in small enterprises only to a very limited extent. Furthermore, we could detect only three South African studies on ABC, namely Naidoo (2011) who investigated the implementation of $\mathrm{ABC}$ on private universities, Sartorius et al. (2007) who investigated the implementation of $\mathrm{ABC}$ in large companies (Johannesburg Stock Exchange listed-companies) and Oberholzer and Van Zyl (2000) who investigated the implementation of ABC in Eskom (South Africa's energy supplier). Other 
related studies are Ziemerink (2008) and Waweru et al. (2005) that briefly refer to ABC in their investigations on management accounting practices in South Africa. In view of the fact that there is little evidence of research conducted to determine the extent to which small manufacturing firms in South Africa have employed ABC, the purpose of this study is to investigate $\mathrm{ABC}$ as a costing approach for this type of firms. Therefore, the specific objectives, with regard to small manufacturing firms are to determine the:

- $\quad$ Extent to which $\mathrm{ABC}$ is adopted.

- $\quad$ Benefits from using and barriers perceived to be impeding adoption of the $\mathrm{ABC}$ system.

- $\quad$ Experience of $\mathrm{ABC}$ practical issues and reasons why firms do not adopt $\mathrm{ABC}$.

This research fulfills the objectives by investigating the differences in firms' profiles, age and size, of firms who implemented $\mathrm{ABC}$ ( $\mathrm{ABC}$ users) and those who did not (non-users); comparing the difference in the perception of firms that implemented $\mathrm{ABC}$ and those who did not regarding the benefits and barriers of $\mathrm{ABC}$; ranking the practical issues of $\mathrm{ABC}$ using the experience of $\mathrm{ABC}$ users, and finally, ranking the reasons for not adopting $\mathrm{ABC}$, given by the non-users. For convenience, the population chosen was small manufacturing firms in the Southern Region of the Gauteng Province in South Africa. The survey was executed during March and April 2012, where 80 questionnaires were hand-delivered to small manufacturing firms operating in this region. The participants in the study were representative of owners/managers/finance staff of the firms. A total of 48 questionnaires were returned, representing a response rate of $60 \%$. The central argument of this study is that the age, size and perceptions of firms who implemented $\mathrm{ABC}$ may differ from those who did not. Furthermore, firms who implemented $\mathrm{ABC}$ are in the best position to share their experience regarding the practical issues of $\mathrm{ABC}$ and firms who did not adopt $\mathrm{ABC}$ can share the reasons for their decision in this regard.

The study indeed found differences between the firms' profiles that implemented $\mathrm{ABC}$ and those who did not, as well as differences in the perception of these two groups regarding the benefits and barriers of $\mathrm{ABC}$. The contribution is that it fills the gap of missing knowledge as a result of the lack of empirical research on $\mathrm{ABC}$ in small manufacturing firms and especially the lack of empirical research on ABC in South African firms.

The rest of the paper is organized as follows: The next section provides a background to the study, followed by a section that explains the theory that forms the basis for the questionnaire. Next is a section that explains the method of the study, which is followed by a section that reveals the finding and a section for a summary of the findings and conclusions. The study is summarized and the practical implications explained in the final section.

\section{BACKGROUND}

\section{Conceptual scope}

The conceptual scope of the study is that small manufacturing firms are facing ever-increasing competition in today's global market environment. Therefore, these enterprises are striving very hard to become more competitive by manufacturing high-quality, low-cost products. The success of firms depends on the value that can be delivered to customers (Drury, 2011), hence for them to remain competitive, make proper decisions, do accurate planning and have effective control, accurate and up-to-date costing information must be available. According to Roden and Dale (2001), not having a proper costing system in place will result in lost orders and opportunities. Failure to maintain strict controls over costs can ultimately result in massive financial losses, damage to reputation and goodwill and even to organizational failure (Merchant \& Van der Stede, 2007). Finally, the traditional costing, using mainly one volume-based cost driver, has lost relevance in a manufacturing environment (Johnson \& Kaplan, 1987).

\section{Key concepts}

Small manufacturing firms

A firm is regarded as small if it has a relatively small share of the market place, is managed by owners or part owners in a personalized way and has fewer than 50 employees (Abor \& Quartey, 2010). Researchers use 
different measures to determine firm sizes, e.g. studies such as Chen et al. (2008) and Theunissen, (2010) used total assets as a company determinant, while Chen et al. (2008) also used expenses, Cordeiro et al. (2006) used sales, and Nourayi and Daroca (2008) used, similar to this study, the number of employees as a proxy for firm size. The literature is not consistent with regard to the number of employees, for example, according to Needy et al. (2003), a small manufacturing firm has fewer than 100 employees. This was also used as a cut-off point in this study.

Small enterprises are the vital drivers of the economic transformation envisaged for any economy. Small firms contribute to output and to the creation of employment opportunities, and are seen as efficient and prolific job creators, the seeds of big businesses and the fuel of national economic engines. In South Africa, it is estimated that $91 \%$ of the formal business entities are small to medium enterprises and their contribution towards the Gross Domestic Product is between 52\% and 57\% and they contribute about $61 \%$ to the national employment figure (Abor \& Quartey, 2010). In addition, small firms ensure income stability, enhance economic growth, upgrade human capital and contribute to poverty alleviation (Elliot \& Boshoff, 2007). Furthermore, small firms also contribute to a country's national product by manufacturing goods for both general public consumers and for enterprises of various sizes, and they contribute directly and often significantly to aggregate savings and investments.

Notwithstanding the recognition of the important roles small enterprises play in a country, their development is largely constrained by a number of factors, such as lack of access to appropriate technology; limited access to international markets, the existence of laws, regulations and rules that impede development, lack of management skills, training and lack of finance (Abor \& Quartey, 2010).

\section{Southern Gauteng Region}

Although geographically the smallest of the nine provinces, Gauteng (seSotho word for "place of gold") contributes more than a third of South Africa's Gross Domestic Product (Wikipedia, 2012a). The Southern Gauteng region is governed by the Southern Gauteng Municipality (also known as the Sedibeng District Municipality), which encompasses the municipalities of Emfuleni, Midvaal and Lesedi. The district is dominated by manufacturing that contributes $32 \%$ to the local economy (Wikipedia, 2012b). The total area consists of $4173 \mathrm{~km}^{2}(1611 \mathrm{sq}$ mi) with a population of approximately 860000 people and 240000 households (Statistics South Africa, 2008).

\section{Activity-based costing}

One innovative costing method that was designed to deal with the deficiencies of traditional costing is $\mathrm{ABC}$. A primary reason for the development of $\mathrm{ABC}$ is its ability to provide more accurate cost information for companies operating in today's globally competitive market (Needy et al., 2003). ABC is a costing approach that assigns resource costs to cost objects such as products, services or customers, based on the activities performed for the cost objects (Hansen \& Mowen, 2006; Thyssen et al., 2006; Blocher et al., 2008).

$\mathrm{ABC}$ was developed to provide a means to create a more accurate representation of how activities performed in the creation of a product or service actually affect its cost (Gupta \& Galloway, 2003). Managers get to know the factors that trigger costs and how they must manage them and it is also used as a supporting infrastructure to aid managers to make decisions, e.g. medium and long-term decisions such as make-or-buy, pricing and special orders (Homburg, 2004). Furthermore, ABC has been promoted and adopted as a basis for making strategic decisions for improving profit performance (Cagwin \& Bouwman, 2002).

$\mathrm{ABC}$ is a two-stage approach for allocating indirect costs to cost objects based on cost drivers at various levels of activity. The first stage assigns factory overhead costs to activities or activity cost centers by using appropriate resource consumption cost drivers. The second stage assigns the cost of activities or activity cost pools to cost objects using appropriate activity consumption cost drivers. Gunasekaran and Sarhadi (1998) stated that ABC can be used to identify non-value adding activities and eliminate them with the objective to improve the performance of a manufacturing system. 


\section{Relevance of the study}

Due to the pressures of the competitive environment, companies should ensure that pricing structures are efficient and effective. $\mathrm{ABC}$ addresses the pricing distortions that exist in traditional costing systems (Raz \& Elnathan, 1999), and managers are provided with a holistic view of cost management. It provides better profitability measures and improved product costing that leads to a better estimate of job costs for pricing decisions (Blocher $e t$ al., 2008). This study's focus is to investigate $A B C$ as a costing approach in small manufacturing firms in South Africa. Therefore, the open question is, in the context of small manufacturing firms, whether ABC is really that superior to traditional costing as promoted by the literature?

\section{THEORY}

To summarize, the central argument of this study is that the age, size and perceptions of firms who implemented $\mathrm{ABC}$ may differ from those who did not and that firms who implemented $\mathrm{ABC}$ are in the best position to share their experience regarding the practical issues of $\mathrm{ABC}$ and firms who did not adopt $\mathrm{ABC}$ can share the reasons for their decision in this regard. The next part is a more in-depth discussion of ABC. This is not merely a summary of existing theory! This theoretical discussion serves as a basis to develop the questionnaire, e.g. the discussion of the benefits and barriers of $\mathrm{ABC}$ were used to develop Sections $\mathrm{B}$ and $\mathrm{C}$ of the questionnaire, respectively, the discussion of the benefits, origin and objectives were used to develop Section $\mathrm{D}$, the practical issues of $\mathrm{ABC}$, and the barriers, origin and objectives were used to develop Section $\mathrm{E}$, the reasons for not adopting ABC. (See the method of the study for further detail.)

\section{Activity-based costing: Origin and objectives}

Traditional costing systems were developed decades ago, when most manufacturers produced a narrow range of products. More recently, manufacturers have started producing a wider range of products, and the conventional methods were no longer sufficient to accurately allocate overhead costs to products and services. It is against this background that $\mathrm{ABC}$ has emerged as an alternative to conventional costing systems (Drury, 2011). $\mathrm{ABC}$, a process of individually listing and measuring the cost of each activity contributing to the production and delivery of a particular product or service, was developed in the USA by Harvard Business School Professors Kaplan and Cooper, in order to overcome some of the limitations of the traditional costing system (Drury, 2011). $\mathrm{ABC}$ was designed with the objective of providing managers with accurate activity-based costing information by using cost drivers to assign activity costs to products and services (Banker et al., 2008). ABC became a popular costing tool amongst manufacturing companies in the 1980s, and has gained popularity in recent decades (Needy $e t$ al., 2003). The objectives of an ABC system are to (Helberg et al., 1994):

- $\quad$ Allocate costs according to the activities consumed;

- $\quad$ Create transparency in the overhead area;

- $\quad$ Provide information for control purposes;

- $\quad$ Relate to the strategy of the company; and

- $\quad$ Improve all operating activities (i.e. support manufacturing excellence).

Increasing competitiveness worldwide has forced manufacturing organizations to seek to produce high quality products more quickly and at a competitive cost. In order to reach these goals, today manufacturing companies are required to become more flexible, integrated and highly automated. However, without a realistic and more accurate cost calculation mechanism, these systems cannot be expected to sustain competitiveness (Ozbayrak et al., 2004). There is a need for changes in the cost accounting system to measure the performance of firms more accurately. The accounting systems help to decide about the product mix and capital investments (Gunasekaran \& Sarhadi, 1998). These changes can be brought about by the use of ABC, since it can overcome many of the limitations of the traditional costing systems. 


\section{Benefits derived from implementing $\mathrm{ABC}$}

Over the past decades, the paradigm of $\mathrm{ABC}$ has helped many manufacturing and service organizations to improve their competitiveness by enabling them to make better decisions based on better understanding of their cost structure (Raz \& Elnathan, 1999). It has been asserted that ABC is a procedure that improves the accuracy of product or service costing and also assists managers in understanding and evaluating how resources are used across a firm's value-chain in delivering strategic outcomes. Raz and Elnathan (1999) have stated that ABC systems address the pricing distortions which exist in traditional cost accounting systems. ABC provides operational cost data and discretionary project cost data. In addition, the approach assigns a more factual basis for decision-making, involving changing the product option offered, profitability and long term strategies to achieve sustainable competitive advantage (Berts \& Kock, 1995). Innes and Mitchell (1997) have indicated that ABC gives visibility to costs by detailing the organization's activities and their respective costs.

Innes and Mitchell (1997, 1990), Banker et al. (2008) and Blocher et al. (2008) outline the following benefits of using $\mathrm{ABC}$ :

- $\quad$ Provides more accurate product line costing particularly where non-volume related overheads are significant and a diverse product line is manufactured.

- Is flexible enough to analyze costs by cost objectives other than products such as processes, area of managerial responsibility and customers.

- Aids identification and understanding of cost behavior and thus has the potential to improve cost estimation. $\mathrm{ABC}$ provides plant managers with a more structured approach to evaluate the expenses associated with specific activities used to support a product

- It provides more accurate product and customer profitability measurements and better-informed strategic decisions about pricing, product lines and market segments.

- It provides more accurate measurements of activity-driving costs, helping managers to improve product design decisions, better customer support decisions and fostering value-enhanced projects.

- It provides the information to identify areas where process improvement is needed.

- Improved product costs lead to better estimates for job costs for pricing decisions, budgeting and planning.

- It provides better information to identify the cost of unused capacity and maintain a separate accounting for this cost.

\section{Barriers impeding the adoption of $\mathrm{ABC}$}

$\mathrm{ABC}$, though it provides better information for product costing than the traditional costing system, is not a cure-all for all managerial concerns (Raiborn \& Kinney, 2009). The barriers that impede ABC adoption by companies may be the individual barriers, organizational and environmental. Individual barriers are related to fear of unknown or shift in status quo, potential loss of status or a necessity to learn new skills. Organizational barriers are often related to territorial or corporate culture issues. Environmental barriers are often built by employee groups, regulatory agencies or other stakeholders of interest (Raiborn \& Kinney, 2009).

Although $\mathrm{ABC}$ provides better product or service costs than the volume-based systems, managers should be aware of its limitations, namely (Blocher et al., 2008):

- Not all costs have appropriate or unambiguous activity or resource consumption cost drivers. Some costs require allocations to departments and products based on arbitrary volume measures because finding the activity that causes cost is impractical.

- $\quad$ Product or service costs identified by an $\mathrm{ABC}$ system are likely to not include all costs associated with the product or service.

- $\quad \mathrm{ABC}$ is not cost-free and is time-consuming to develop and implement.

Implementing and operating an $\mathrm{ABC}$ system is significantly more expensive than operating a traditional costing system and in particular the training and software requirements may prohibit its adoption by small 
companies (Drury, 2011). Raiborn and Kinney (2009) confirm that ABC requires a significant amount of time and thus costly to implement and it does not conform specifically to Generally Accepted Accounting Principles (GAAP). It suggests that some non-product costs should be allocated to products, whereas certain other traditionally designated product costs should not be allocated to products. To summarize, managers of small manufacturing companies may be overwhelmed by the time and effort required to develop an extensive ABC system (Needy et al., 2003).

\section{Hypothesis}

Since the implementation of $\mathrm{ABC}$ is expensive and requires skills and knowledge, the expectation is that differences in the firms' profile, such as age and size, play a role when a decision has to be made whether ABC should be adopted or not. The first two null-hypotheses are stated in this regard:

H1 There is no mean difference in the age of firms who implemented $\mathrm{ABC}$ and those who did not.

H2 There is no mean difference in the size (number of employees) of firms who implemented $\mathrm{ABC}$ and those who did not.

Since the firms that have implemented $\mathrm{ABC}$ have more practical experience than the firms who did not adopt $\mathrm{ABC}$, it can be hypothesized that the perceptions regarding the benefits and barriers of $\mathrm{ABC}$ is different between these two groups. The third and fourth hypotheses are stated in this regard:

H3 There are no mean differences between the perception of benefits derived from implementing $\mathrm{ABC}$ of firms who implemented $\mathrm{ABC}$ and those who did not.

H4 There are no mean differences between the perception of perceived barriers impending the adoption of $\mathrm{ABC}$ of business who implemented $\mathrm{ABC}$ and those who did.

\section{METHOD}

\section{Sample and response}

The data was collected by means of structured questionnaires that were hand-delivered to the owners/managers/finance staff of small manufacturing firms operating in the Southern Gauteng region. The cover letter outlined the purpose of the study as well as ensuring anonymity of the responses.

For this study, however, a convenience sample, sometimes called grab or opportunity sampling, is used. Its main disadvantage is that it is classified as non-probability sampling, because elements in the population are included since they are easily and conveniently available, but not necessarily representative of the population (Maree, 2011). Therefore, convenience sampling is the method of choosing items in an unstructured manner from the population frame. However, it is chosen because respondents can be reached easily, costs can be kept to a minimum and most importantly, it is useful in exploratory research to get a quick approximation of the truth (Maree, 2011). A sample of 80 small manufacturing firms within Southern Gauteng was selected according to a list obtained from the Vaal Information Directory (2012) and from the Yellow Pages (2012).

In total, 48 respondents completed the questionnaire, which represents a response rate of $60 \%$, where 16 and 32 respondents indicated that they have adopted/ not-adopted ABC, respectively. (Note that only 30 of the 32 respondents completed Section E of the questionnaire.)

\section{The questionnaire}

The questionnaire was divided into five sections; Section A focuses on the firm's profile (age and size in terms of number of employees), Section B focuses on the perceived benefits derived from implementing ABC, Section $\mathrm{C}$ focuses on the perceived barriers impeding the respondents' adoption of $\mathrm{ABC}$, Section $\mathrm{D}$ concentrates on 
the practical issues of $\mathrm{ABC}$ within small companies and Section $\mathrm{E}$ refers to those companies that have not implemented $\mathrm{ABC}$ and the reasons for not adopting $\mathrm{ABC}$. Except for the question regarding the firms' profiles, the questionnaire comprised a five-point Likert scale and the respondents were instructed by the researcher during the administration of the questionnaire to circle the most suitable answer. The scale ranged from 1 to 5 as follows:

1. Strongly disagree;

2. Disagree;

3. Neutral;

4. Agree;

5. Strongly agree.

\section{Data analysis}

In respect of the statistical analysis, the means (averages) of the age, size, and perceptions of the benefits and barriers of firms who implemented $\mathrm{ABC}$ are compared with the firms who did not adopt $\mathrm{ABC}$. The t-test, which is suitable for smaller samples (Swanepoel et al., 2010), was performed to determine whether the differences between these two independent group's means are significant. Since Microsoft Excel was used, the F-test was first performed to determine whether a t-test, assuming equal variances, or a t-test, assuming unequal variances, should be run (Arthur, 2009). A null-hypothesis is stated that there is no difference between the means of the two sets of data. A significant level of $\rho<\alpha=0.05$ is used, implying that $p<0.05$ assumes unequal variances and $p>0.05$ assumes equal variances. Since this is a two-sided approach, the two-tail values were used in the statistical analysis.

The t-test was based on the following significant levels, where $\rho<\alpha=0.01$ and $\alpha=0.05$, respectively (twotailed) implying that there is overwhelming and strong evidence, respectively, that the null-hypothesis should be rejected in favor of the alternative hypothesis. Where $\mathrm{p}>\alpha=0.05$, the null-hypothesis will not be rejected since there is weak or no evidence to accept the alternative hypothesis (Wegner, 2007).

\section{Validity and reliability}

A pilot study was executed in order to test the reliability of the measuring instrument. Pilot testing of the instrument was undertaken to ensure that the questionnaire was clear and understandable. The candidates of the pilot testing consisted of 15 small firms operating in the Southern Gauteng region, who were encouraged to raise any queries experienced while completing the questionnaire. The general response from the pilot study was positive and resulted in only minor changes in wording and layout of the questionnaire.

The Cronbach Alpha coefficient was used to measure the internal reliability of the measuring instrument. The Cronbach Alpha coefficient for Sections B and C, which are completed by all the respondents $(\mathrm{n}=48)$, is 0.71 , for Section $\mathrm{D}$, which is completed by the users of $\mathrm{ABC}(\mathrm{n}=16)$, is 0.80 and Section $\mathrm{E}$, which is completed by the non-users of $\mathrm{ABC}(\mathrm{n}=30)$, is 0.74 . The questionnaire was found to be valid and reliable since the Cronbach Alpha coefficients are all above 0.70 (Gwet, 2012).

\section{FINDINGS}

The findings of the questionnaire are presented under the following three topics, firstly the difference in firms' profiles between those who implemented $\mathrm{ABC}$ and those who did not; secondly the difference in perceptions of benefits and barriers between firms who implemented $\mathrm{ABC}$ and those who did not, and thirdly the report on the experience of the practical issues of $\mathrm{ABC}$ by the firms who implemented $\mathrm{ABC}$ and the reasons given by the remaining firms of not adopting $\mathrm{ABC}$.

\section{Difference in firms' profiles}

The first two questions were asked to better understand the firms' profiles. The first question posed to the respondents was to indicate on a five-point scale how long they are in business, where 1 represents less than one year, 2 between one and two years, 3 between 2 and 5 years, 4 between five and ten years and 5 more than ten years. 
Table 1 indicates that the average (mean) score for firms who adopted $\mathrm{ABC}$ is 4.5 years, implying that most of the firms fall between five to ten years and more than ten years categories. The standard deviation is also included, indicating how the data is spread around the mean. The average score for the non-users is 4.094, meaning that these firms have been in business for a shorter period than the users of ABC. To test the null-hypothesis (H1), there is no mean difference in the age of businesses who implemented $\mathrm{ABC}$ and those who did not, Table 1 indicates that there is strong evidence to reject the null-hypothesis in favor of the alternative hypothesis, meaning that the time in business for the $\mathrm{ABC}$ users is significantly longer than it is for the non-users.

Table 1: Difference of firms' profiles between users and non-users of ABC

\begin{tabular}{|c|c|c|}
\hline Users $(n=16)$ & Age & Size \\
\hline Mean & 4.500 & 67.688 \\
\hline Std dev. & 0.516 & 18.180 \\
\hline \multicolumn{3}{|c|}{ Non-users $(n=32)$} \\
\hline Mean & 4.094 & 43.875 \\
\hline Std dev. & 0.641 & 17.277 \\
\hline \multicolumn{3}{|l|}{ F-test } \\
\hline p-value & 0.190 & 0.390 \\
\hline \multicolumn{3}{|l|}{ t-test } \\
\hline p-value & 0.033 & $<0.001$ \\
\hline Significance & $* *$ & $* * *$ \\
\hline
\end{tabular}

** Significant at 5\% and *** significant at 1\% (two-tailed)

Source: Own calculations

The second question required from the respondents to indicate the size of their firms in terms of the number of employees. Table 1 indicates that the users of $\mathrm{ABC}$ and non-users employ on average 67.688 and 43.875 workers, respectively. (The users employ between 41 and 96 workers while the minimum and maximum numbers for the nonusers are 17 and 78.) To test the null-hypothesis (H2), there is no mean difference in the size (number of employees) of business who implemented $\mathrm{ABC}$ and those who did not; the evidence is overwhelming that the nullhypothesis should be rejected, implying that the size of the firms that implemented $\mathrm{ABC}$ is significantly larger than those who did not.

\section{Difference in perceptions of benefits and barriers}

Section B of the questionnaire tested the perception of respondents regarding the benefits derived from implementing $\mathrm{ABC}$. Table 2 indicates the individual statements of Section $\mathrm{B}$, where a range from 1 to 5 was used indicating "strongly disagree" to "strongly agree".

Table 2: Statements regarding the benefits of adopting $\mathrm{ABC}$

\begin{tabular}{|l|l|}
\hline Statements & \multicolumn{1}{|c|}{ Increased profitability } \\
B1 & More accurate product cost \\
B3 & Improved performance measurement \\
B4 & Assistance in cost-reduction efforts \\
B5 & Assistance in managing and controlling budgets \\
B6 & Better decision-making and control \\
B7 & Increased customer satisfaction \\
B8 & Elimination of waste by providing visibility of non-value-added activities \\
B9 & Cost control improvement \\
B10 & Improvement in shareholder value \\
B11 & ABC has increased the companies competitiveness in the market \\
\hline
\end{tabular}

Source: Own research

Table 3 indicates that the null-hypothesis should be rejected, implying that there is a significant difference between the perception of $\mathrm{ABC}$ users and non-users, where the $\mathrm{ABC}$ users agree more (higher mean scores) than the non-users that $\mathrm{ABC}$ provides: Assistance in managing and controlling budgets (B5); a basis for better decisionmaking and control (B6); and provided an increase in the firms' competiveness in the market (B11). For the rest of the statements in Section B, the null-hypothesis should not be rejected, implying there is no difference between the perceptions of $\mathrm{ABC}$ users and non-users. 
Table 3: Difference between users' and non-users' perceptions of the benefits of ABC

\begin{tabular}{|lccccccccccc|}
\hline Users (n=16) & $\mathbf{B 1}$ & $\mathbf{B 2}$ & $\mathbf{B 3}$ & $\mathbf{B 4}$ & $\mathbf{B 5}$ & $\mathbf{B 6}$ & $\mathbf{B 7}$ & $\mathbf{B 8}$ & $\mathbf{B 9}$ & $\mathbf{B 1 0}$ & $\mathbf{B 1 1}$ \\
Mean & 4.063 & 4.125 & 3.688 & 4.063 & 4.125 & 4.250 & 3.500 & 3.438 & 4.188 & 3.250 & 3.938 \\
Std dev. & 0.574 & 0.619 & 0.602 & 0.574 & 0.719 & 0.447 & 0.516 & 0.629 & 0.403 & 0.447 & 0.443 \\
Non-users (n=32) & & & & & & & & & & \\
Mean & 4.156 & 4.094 & 3.813 & 4.000 & 3.719 & 3.875 & 3.531 & 3.438 & 4.031 & 3.281 & 2.938 \\
Std dev. & 0.369 & 0.296 & 0.397 & 0.359 & 0.523 & 0.336 & 0.507 & 0.504 & 0.177 & 0.457 & 0.504 \\
\hline $\begin{array}{l}\text { F-test } \\
\text { p-value }\end{array}$ & 0.018 & 0.000 & 0.024 & 0.013 & 0.065 & 0.087 & 0.447 & 0.145 & 0.000 & 0.483 & 0.303 \\
t-test & & & & & & & & & & & \\
p-value & 0.558 & 0.850 & 0.460 & 0.694 & 0.030 & 0.002 & 0.842 & 1.000 & 0.156 & 0.823 & 0.000 \\
Significance & & & & & $* *$ & $* * *$ & & & & & \\
\hline
\end{tabular}

** Significant at $5 \%$ and $* * *$ significant at $1 \%$ (two-tailed)

Source: Own calculations

Section $\mathrm{C}$ of the questionnaire tested the perception of respondents regarding the perception of perceived barriers impeding the adoption of $\mathrm{ABC}$ by firms who implemented $\mathrm{ABC}$ and those who did not adopt $\mathrm{ABC}$. Table 4 indicates the individual statements of Section $\mathrm{C}$, where a range from 1 to 5 was used indicating "strongly disagree" to "strongly agree".

Table 4: Statements regarding the barriers ABC

\begin{tabular}{|l|l|}
\hline Statements & \\
\hline C1 & High cost of implementing ABC \\
C2 & Resistance to change \\
C3 & Involves a great deal of work \\
C4 & It is time consuming \\
C5 & Lack of top management support \\
C6 & Lack of cooperation and commitment among departments \\
C7 & Lack of knowledge concerning ABC \\
C8 & Problems in defining cost drivers \\
C9 & Problems in identifying activities \\
C10 & High cost of consultations \\
C11 & A higher priority of other changes or projects \\
\hline
\end{tabular}

Source: Own research

Table 5 indicates that the null-hypothesis should be rejected, implying that there is a significant difference between the perception of $\mathrm{ABC}$ users and non-users, where the non-users agree more (higher mean scores) than the $\mathrm{ABC}$ users that barriers impeding the adoption of $\mathrm{ABC}$ are: A lack of knowledge concerning $\mathrm{ABC}(\mathrm{C} 7)$; problems in defining cost drivers (C8); problems in identifying activities (C9); and there is a higher priority of other changes or projects (C11). For the rest of the statements in Section $\mathrm{C}$, the null-hypothesis should not be rejected, implying that there is no difference between the perceptions of $\mathrm{ABC}$ users and non-users.

Table 5: Difference between users' and non-users' perceptions of the barriers of ABC

\begin{tabular}{|lccccccccccc|}
\hline Users (n=16) & $\mathbf{C 1}$ & $\mathbf{C 2}$ & $\mathbf{C 3}$ & $\mathbf{C 4}$ & $\mathbf{C 5}$ & $\mathbf{C 6}$ & $\mathbf{C 7}$ & $\mathbf{C 8}$ & $\mathbf{C 9}$ & $\mathbf{C 1 0}$ & $\mathbf{C 1 1}$ \\
Mean & 4.375 & 4.000 & 4.438 & 4.250 & 2.875 & 3.125 & 3.313 & 2.875 & 2.875 & 4.375 & 2.938 \\
Std dev. & 0.885 & 0.730 & 0.814 & 0.775 & 1.147 & 1.025 & 0.793 & 0.885 & 0.885 & 0.806 & 0.250 \\
Non-users (n=32) & & & & & & & & & & \\
Mean & 4.656 & 4.063 & 4.500 & 4.625 & 3.281 & 3.281 & 4.031 & 3.781 & 3.813 & 4.625 & 3.719 \\
Std dev. & 0.483 & 0.504 & 0.508 & 0.492 & 0.813 & 0.772 & 0.595 & 0.491 & 0.535 & 0.492 & 0.523 \\
\hline F-test & & & & & & & & & & & \\
p-value & 0.002 & 0.040 & 0.013 & 0.016 & 0.051 & 0.089 & 0.086 & 0.003 & 0.009 & 0.010 & 0.002 \\
t-test & & & & & & & & & & \\
p-value & 0.250 & 0.761 & 0.781 & 0.092 & 0.163 & 0.557 & 0.001 & 0.001 & 0.001 & 0.268 & 0.000 \\
Significance & & & & & & & $* * *$ & $* * *$ & $* * *$ & & $* * *$ \\
\hline
\end{tabular}

** Significant at $5 \%$ and $* * *$ significant at $1 \%$ (two-tailed)

Source: Own calculations 


\section{Practical issues of $\mathrm{ABC}$ and reasons for not implementing $\mathrm{ABC}$}

Table 6 exhibits the ranking of eight statements posed to the respondents regarding some practical issues of $\mathrm{ABC}$, where a range from 1 to 5 was used indicating "strongly disagree" to "strongly agree". These eight statements were rated in a relative narrow range, from 3.53 to 2.53 , the highest and the lowest agreed statements. This narrow range, with an average close to 3 on the Likert scale, is evidence that the respondents' opinions are to a great extent "neutral" in respect of these statements. Nevertheless, the highest-ranked statement is that ABC's benefits have exceeded the cost of implementing it.

Table 6: Ranking of practical issues of $\mathrm{ABC}(\mathrm{n}=16)$

\begin{tabular}{|c|c|c|c|}
\hline Rank & & Mean & Std dev. \\
\hline 1 & $\mathrm{ABC}$ benefits have exceeded the cost of implementing it & 3.53 & 0.52 \\
\hline 2 & Top management has provided adequate resources to $\mathrm{ABC}$ initiative & 3.40 & 1.30 \\
\hline 3 & $\mathrm{ABC}$ is tied to the competitive strategies of the business & 3.40 & 0.63 \\
\hline 4 & $\begin{array}{l}\text { The top management are/ were committed to use the } \mathrm{ABC} \text { information as the basis for } \\
\text { decision making }\end{array}$ & 3.33 & 0.98 \\
\hline 5 & $\begin{array}{l}\text { Compensation systems in the company have been designed to motivate employees to } \\
\text { implement } \mathrm{ABC}\end{array}$ & 2.93 & 0.59 \\
\hline 6 & There has been consensus about the objectives and aims of $\mathrm{ABC}$ & 2.93 & 0.96 \\
\hline 7 & $\begin{array}{l}\text { The objectives and purpose of the } \mathrm{ABC} \text { implementation were clearly stated and } \\
\text { understood by both designers and users }\end{array}$ & 2.87 & 0.92 \\
\hline 8 & Adequate training is/was provided for implementing $\mathrm{ABC}$ & 2.53 & 0.52 \\
\hline
\end{tabular}

Source: Own research

Table 7 exhibits the ranking of 12 statements posed to the respondents regarding to the reasons why their firm did not adopt $\mathrm{ABC}$, where a range from 1 to 5 was used to indicate "strongly disagree" and "strongly agree". The high means of the first four statements indicate that respondents highly agreed that $\mathrm{ABC}$ is too expensive, there is a lack of adequate systems, it's too detailed/time consuming and they have a lack of skills/knowledge regarding to ABC. These findings are in line with the findings of Needy et al. (2003) and Raiborn and Kinney (2009).

Table 7: Ranking of reasons for not adopting ABC $(\mathbf{n}=30)$

\begin{tabular}{|c|c|c|c|}
\hline Rank & & Mean & Std dev. \\
\hline 1 & Too expensive to implement & 4.87 & 0.35 \\
\hline 2 & Lack of adequate systems & 4.57 & 0.50 \\
\hline 3 & Too detailed, time consuming & 4.50 & 0.51 \\
\hline 4 & Lack of skills/ knowledge of $\mathrm{ABC}$ & 3.80 & 0.85 \\
\hline 5 & Difficulty defining cost pools, cost drivers & 3.23 & 0.63 \\
\hline 6 & Difficulty identifying suitable cost drivers & 3.20 & 0.55 \\
\hline 7 & Difficulty with data & 3.20 & 0.66 \\
\hline 8 & Difficulty configuring $\mathrm{ABC}$ with other systems & 3.13 & 0.35 \\
\hline 9 & Inadequate marketing of $\mathrm{ABC}$ & 3.03 & 0.56 \\
\hline 10 & Satisfaction with the current system & 2.63 & 0.93 \\
\hline 11 & Does not add value & 2.43 & 0.73 \\
\hline 12 & Negative publicity about ABC & 2.23 & 0.77 \\
\hline
\end{tabular}

Source: Own research

\section{SUMMARY OF FINDINGS AND CONCLUSIONS}

The findings in the research highlight a number of issues concerning the application of $\mathrm{ABC}$ and the perceptions of respondents towards $\mathrm{ABC}$ within small manufacturing companies in Southern Gauteng region. These are summarized as follows:

- $\quad$ The study found that there is strong evidence that the time that $\mathrm{ABC}$ users have been in business is significantly longer than the time that non-users have been in business (Table 1).

- $\quad$ The size, in terms of number of employees, of $\mathrm{ABC}$ user firms is significantly larger than the size of the non-user firms (Table 1). 
- $\quad$ Regarding the differences in the perception of $\mathrm{ABC}$ users and non-users, the study found that $\mathrm{ABC}$ users rated the following three of 11 benefits of $\mathrm{ABC}$ significantly higher than the non-users, namely that $\mathrm{ABC}$ provides: Assistance in managing and controlling budgets; A basis for better decision-making and control; and Increased the firms' competiveness in the market (Table 3).

- $\quad$ Regarding the differences in the perception of $\mathrm{ABC}$ users and non-users, the study found that the following four of 11 barriers of implementing $\mathrm{ABC}$ are rated significantly higher by the non-users, namely: A lack of knowledge concerning ABC; Problems in defining cost drivers; Problems in identifying activities; and That there is a higher priority of other changes or projects (Table 5).

- $\quad$ The eight statements posed to $\mathrm{ABC}$ users regarding their experience of some practical issues of $\mathrm{ABC}$ reveal that the statements were rated in a relatively narrow range with an average close to the middle of the Likert scale is evident that the respondents' opinions are to a great extent "neutral" in respect of these statements. Nevertheless, the highest ranked statement is that ABC's benefits have exceeded the cost of implementing it (Table 6).

- $\quad$ The ranking of 12 statements posed to the non-users of $\mathrm{ABC}$ revealed that respondents highly agreed that $\mathrm{ABC}$ is too expensive, there is a lack of adequate systems, it's too detailed/time consuming and they have a lack of skills/knowledge regarding to $\mathrm{ABC}$ (Table 7).

From these findings, the following conclusions can be deduced:

- $\quad$ The fact that the $\mathrm{ABC}$ users have been in business significantly longer than the non-users and that nonusers indicated the main reasons for not implementing $\mathrm{ABC}$ as it being too expensive, a lack of adequate supporting systems and a lack of knowledge, implying that a small manufacturing business needs time to grow to overcome these obstacles to implementing $\mathrm{ABC}$. In other words, they need time to grow to enable them to afford an $\mathrm{ABC}$ system, to get other supporting systems in place and get skills and knowledge to implement and operate an $\mathrm{ABC}$ system.

- $\quad$ Furthermore, with the main reasons in mind for not implementing $A B C$, namely that $A B C$ is too expensive, and the fact that the $\mathrm{ABC}$ users' firms are significantly larger than the non-users firms', it implies that larger firms are probably in a better financial position to afford such a system.

- $\quad$ Since the $\mathrm{ABC}$ users rated three of 11 benefits significantly higher than the non-users it is evident that there is a difference in the perceptions between the two groups in this regard. The fact that the ABC users rated the three benefits significantly higher than the non-users (Assistance in managing and controlling budgets; A basis for better decision-making and control; and increased the firms' competiveness in the market) implies that the non-users under-estimate these benefits significantly.

- $\quad$ Since the non-users rated four of 11 barriers of implementing $A B C$ significantly higher than $A B C$ users it is evident that there is a difference in the perceptions between the two groups in this regard. The lesson that non-users can learn from the $\mathrm{ABC}$ users is that these barriers (A lack of knowledge concerning $\mathrm{ABC}$; Problems in defining cost drivers; Problems in identifying activities; and That there is a higher priority of other changes or projects) should not be as much of a problem than they believe it is.

- $\quad$ The fact that the $\mathrm{ABC}$ users are to a great extent neutral to the practical issues of $\mathrm{ABC}$ implies that implementing $\mathrm{ABC}$ did not bring about extraordinary or unexpected advantages to their firms.

\section{SUMMARY AND PRACTICAL IMPLICATIONS}

This study is an empirical investigation by means of a survey of the experiences and perceptions of $A B C$ as an alternative to traditional costing in small manufacturing firms in the Southern Gauteng region of South Africa. The objectives of the study were to determine the: Extent to which $A B C$ is adopted; Perceptions of the benefits and the barriers of $\mathrm{ABC}$; Experiences regarding the practical issues of $\mathrm{ABC}$; and Reasons for not adopting $\mathrm{ABC}$. An analysis of 48 questionnaires indicated that 16 firms implemented $A B C$ whilst 32 did not implement it. The study concluded that:

- $\quad$ Non-users of $\mathrm{ABC}$ need some time to grow to enable them to afford an $\mathrm{ABC}$ system, to get other supporting systems in place and get skills and knowledge to implement and operate an $\mathrm{ABC}$ system;

- $\quad$ Larger firms are probably in a better financial position to afford an $\mathrm{ABC}$ system. 
- $\quad$ Non-users of $\mathrm{ABC}$ under-estimate some of the benefits of $\mathrm{ABC}$ significantly.

- $\quad$ The lesson that non-users can learn from the $\mathrm{ABC}$ users is that some barriers of implementing $\mathrm{ABC}$ should not be as much of a problem as they believe it is.

- Implementing $\mathrm{ABC}$ did not bring about extraordinary or unexpected advantages to their firms.

With the open question stated earlier in mind, as to whether $A B C$ is really that superior to traditional costing as promoted by the literature, it is clear from the above-mentioned that the implementation of $\mathrm{ABC}$ requires that a firm be well-established, with sufficient funds and knowledge and that $\mathrm{ABC}$ users are to some extent more positive towards $\mathrm{ABC}$ than non-users, but still to a great extent neutral regarding to the listed practical experiences. Therefore, the recommendation is that, since firms are unique, they should do a cost benefit analysis to determine whether it will be worthwhile implementing ABC.

The value of the study is that this is the first attempt to investigate the difference in firms' profiles which have adopted/ not adopted $\mathrm{ABC}$ as well as the perceptions of benefits, barriers of implementing $\mathrm{ABC}$ as well as the experiences regarding some practical issues of $\mathrm{ABC}$ in practice. Although there are not obvious reasons why small manufacturing firms and perceptions about $\mathrm{ABC}$ would differ among the different regions in South Africa, it is important to note that, since the survey was done in the Southern Gauteng region, this study does not claim that these conclusions are valid to all small manufacturing firms or specifically small manufacturing firms in South Africa. Nevertheless, the contribution is that it fills the gap regarding to the lack of empirical research of $\mathrm{ABC}$ in small manufacturing firms and also the lack of empirical research on ABC in South African firms. The practical implication is that owners/managers of small manufacturing firms can better understand these aspects investigated regarding to $\mathrm{ABC}$. The main concern is that $\mathrm{ABC}$ is per se expensive to implement and resources are also needed for establishing other capacities before $\mathrm{ABC}$ can be implemented. Since this study did not investigate a cost-benefit analysis of $\mathrm{ABC}$, it recommended that firms should do a cost-benefit analysis before the implementation of $\mathrm{ABC}$, but further studies should also focus on the cost-benefits of $A B C$ in small manufacturing firms to guide these firms in the decision-making process as to whether $\mathrm{ABC}$ should be implemented or not.

\section{AUTHOR INFORMATION}

Rosebud Rundora is a part-time lecturer in the Accountancy Department (Faculty of Management Sciences) at the Vaal University of Technology in Vanderbijlpark (South Africa). E-mail: Rosebudr@ymail.com

Doctor Toekie Ziemerink is a Senior lecturer in Management Accounting in the Accountancy Department (Faculty of Management Sciences) at the Vaal University of Technology in Vanderbijlpark (South Africa). She is currently lecturing undergraduate students in Management Accounting as well as supervising various Masters' students. E-mail: toekie@vut.ac.za

Professor Merwe Oberholzer is currently Professor in the School of Accounting Sciences at the North-West University (South Africa). He has taught extensively in the Chartered Accountancy and Chartered Management Accountancy programs. His academic research output includes more than 40 peer-reviewed articles and conference presentations. His current research focuses mainly on corporate resilience, - sustainability and DEA modeling. E-mail: Merwe.Oberholzer@nwu.ac.za (Corresponding author)

\section{REFERENCES}

1. Abor, J. \& Quartey, P. (2010). Issues In SME Development In Ghana And South Africa. International Research Journal of Finance and Economics, 39 218-228.

2. $\quad$ Arthur, J. (2009). t Test two sample assuming equal variances in Excel. Retrieved from: http://www.qimacros.com/qiwizard/t-test-two-sample.html

3. Atrill, P. \& Mclaney, E. (2007). Management accounting for decision makers. Essex: Pearson Education.

4. Banker, R.D., Bardhan, I.R. \& Chen, T. (2008). The Role Of Manufacturing Practices In Mediating The Impact Of Activity-Based Costing On Plant Performance. Accounting, Organizations and Society, 33(1) 119. 
5. Berts, K. \& Kock, S. (1995). Implementation Considerations For Activity Based Costing Systems In Service Firms: The Unavoidable Challenge. Management Decision, 33(6) 57-63.

6. Blocher, E., Stout, D.E., Cokins, G. \& Chen, K. (2008). Cost management: A strategic emphasis. New York: McGraw-Hill/Irwin.

7. Cagwin, D. \& Bouwman, M.J. (2002). The Association Between Activity-Based Costing And Improvement In Financial Performance. Management Accounting Research, 13(1) 3-39.

8. Chen, Y., Gregoriou, G.N. \& Rouah, F.D. (2008). Efficiency Persistence Of Bank And Thrift CEOs Using Data Envelopment Analysis. Computers \& Operational Research, 36 1554-1561. Retrieved from: www.elsevier.com/locate/cor

9. Cooper, R. \& Kaplan, R. (1991). Profit Priorities From Activity-Based Costing. Harvard Business Review, May/June, 69(3) 130-135.

10. Cooper, R. \& Slagmulder, R. (1999). Integrating Activity-Based Costing And Economic Value Added. Management Accounting: Official Magazine of Management Accountants, January, 80(7) 16. Business Source Premier, Ipswich, MA. Retrieved from: http://web.ebscohost.com

11. Cordeiro, J.J., Mukherjee, P. \& Kent, D.D. (2006). Non-Parametric Assessment Of CEO Compensation Practices. Management Research News, 29(5) 242-251.

12. Drury, C. (2011). Management and cost accounting. $7^{\text {th }}$ South African edition. Hampshire: South-Western Cengage Learning.

13. Elliot, R. \& Boshoff, C. 2007. The Influence Of The Owner-Manager Of Small Tourism Business Of Internet Marketing. South African Business Journal, 38(3) 15-27.

14. Gunasekaran, A. \& Sarhadi, M. (1998). Implementation Of Activity-Based Costing In Manufacturing. International Journal of Production Economics, 56/57 231-242.

15. Gunasekaran, A. \& Singh, D. (1999). Design Of Activity-Based Costing In A Small Company: A Case Study. Computers and Industrial Engineering, 37 413-416.

16. Gupta, C.M. \& Galloway, K. (2003). Activity-Based Costing/Management And Its Implications For Operations Management. Technovation, 23 131-138.

17. Gwet, K.L. (2012). Handbook of inter-rater reliability. Retrieved from: http://www.agreestat.com/book3/

18. Hansen, D.R. \& Mowen, M.M. (2006). Cost management: Accounting and control. Ohio: Thomson/ SouthWestern.

19. Helberg, C., Galletly, J.E. \& Bicheno, J.R. (1994). Simulating Activity Based Costing. Industrial Management \& Data Systems, 94(9) 3-8.

20. Homburg, C. 2004. Improving Activity-Based Costing Heuristics By Higher Level Cost Drivers. European Journal of Operational Research, 157 332-343.

21. Innes, J. \& Mitchell, F. (1997). An Application Of Activity-Based Costing In The United Kingdom's Largest Financial Institutions, Service Industries Journal, 17(1) 190-203.

22. Innes, J. \& Mitchell, F. (1990). Activity-Based Costing: A Review With Case Studies. Chartered Institute of Management Accountants, London.

23. Liu, Y.H. \& Gong, S.L. (2011). Production Management For Manufacturing Based On Activity-Based Costing. Applied Mechanics and Materials, 120(1) 435-435. E-Journals, Ipswich, MA. Retrieved from: http://search.ebscohost.com

24. Khataie, A.H., Bulgak, A.A. \& Segovia, J.J. (2011). Activity-Based Costing And Management Applied In A Hybrid Decision Support System For Order Management. Decision Support Systems, 52(1) 142-156. Business Source Premier, Ipswich, MA. Retrieved from: http://web.ebscohost.com

25. Johnson, H.T. \& Kaplan, R.S. (1987). Relevance lost: The rise and fall of management accounting. Boston: Harvard Business School Press.

26. Maree, K. (Editor). (2011). First steps in research. Pretoria: Van Schaik.

27. Mersereau, K. (2007). Pushing The Art Of Management Accounting. Journal of the South African Institute of Professional Accountants, 10-14.

28. Merchant, K.A. \& Van der Stede, W.A. (2007). Management control systems performance measurement, evaluation and incentives. Essex: Prentice Hall.

29. Naidoo, M. (2011). Using Activity-Based Costing To Manage Private Universities In South Africa. Problems and Perspectives in Management, 9(4) 109-16.

30. Needy, K.L., Nachtmann, H., Roztocki, N. \& Warner, R.C. 2003. Implementing Activity-Based Costing Systems In Small Manufacturing Firms: A Field Study. Engineering Management Journal, 15(1) 3-10. 
31. Nourayi, M.M. \& Daroca, F.P. (2008). CEO Compensation, Firm Performance And Operational Characteristics. Managerial Finance, 34(8) 562-584.

32. Oberholzer, M. \& Van Zyl, J.A. (2000). “Aktiwiteitsgebaseerde Koste En Bestuur In Eskom Se Brandstofverkrygingsafdeling”. [Activity-Based Costing And Management In Eskom's Fuel Purchases Devision.] Meditari Accounting Research, 8(1) 111-125.

33. Ozbayrak, M., Akgun, M. \& Turker, A.K. (2004). Activity-Based Cost Estimation In A Push/ Pull Advanced Manufacturing System. Journal of Production Economics, 87 49-65.

34. Raiborn, C.A, \& Kinney, M.R. (2009). Cost accounting: Foundations and evolutions. Mason: South Western/ Cengage Learning.

35. Raz, T. \& Elnathan, D. (1999). Activity-Based Costing For Projects. International Journal of Project Management, 17(1) 61-67.

36. Robinson-Backmon, I. (2004). An activity-based costing model for dental schools: Is ABC a feasible costing alternative? Journal of Business and Economic Research. The Clute Institute. Retrieved from: http://journals.cluteonline.com/index.php/JBER/article/view/2866/2914

37. Roden, S. \& Dale, B. (2001). Quality Costing In A Small Engineering Company: Issues And Difficulties. The Total Quality Management, 13(6) 388-399.

38. Sartorius, K., Eitzen, C. \& Kamala, P. (2007). The Design And Implementation Of Activity-Based Costing (ABC): A South Africa Survey. Meditari Accounting Research, 15(2) 1-21.

39. Statistics South Africa. (2008). Community survey, 2007 basic results: Municipalities. Retrieved from: http://www.statssa.gov.za/publications/p03011/p030112007.pdf

40. Swanepoel, J.W.H., Swanepoel, C.J., Van Graan, F.C., Allison, J.S. \& Santana, L. (2010). Elementary statistical methods. Potchefstroom: AndCorp.

41. Theunissen, P. (2010). Is executive remuneration out of control? Bethlehem: Computus/ Hooglandpers.

42. Thyssen, J., Israelsen, P. \& Jorgensen, B. (2006). Activity-Based Costing As A Method For Assessing The Economics Of Modularization: A Case Study And Beyond. International Journal of Production Economics, 103 252-270.

43. Vaal Information Directory. (2012). Retrieved from: www.vaalinfodirectory.co.za

44. Waweru, N.M., Hoque, Z. \& Uliana, E. (2005). A Survey Of Management Accounting Practices In South Africa. International Journal of Accounting, Auditing and Performance Evaluation, 2(3) 226-263.

45. Wegner, T. (2007). Applied business statistics: Methods and Excel-based applications. Cape Town: Juta.

46. Wikipedia. (2012a) Gauteng. Retrieved from: http://en.wikipedia.org/wiki/Gauteng

47. Wikipedia. (2012b). Sedibeng District Municipality. Retrieved from: http://en.wikipedia.org/wiki/Sedibeng_District_Municipality\#Socio_economic_situation

48. Yahya-Zadeh, M. (1998). Product-Mix Decisions Under Activity-Based Costing With Resource Constraints And Non-Proportional Activity Costs. Journal of Applied Business Research. The Clute Institute. Retrieved from http://journals.cluteonline.com/index.php/JABR/article/view/5650/5731

49. Yellow Pages. (2012). Retrieved from: (http://www.yellowpages.co.za/small_businesses/gauteng/lesedi_rural/small_businesses-lesedi_rural/), (http://www.yellowpages.co.za/small_businesses/gauteng/small_businesses-emfuleni_rural/), and http://www.yellowpages.co.za/small_businesses/gauteng/midvaal/small_businesses-midvaal/

50. Zhang, Y.F. and Che, R.I. (2011). The Effect Of Activity-Based Costing On Firms Performance, A Study Among Chinese Manufacturing Firms. Journal of Applied Sciences Research, 7(9) 227-237. Computers \& Applied Sciences Complete, Ipswich, MA. Retrieved from: http://web.ebscohost.com

51. Ziemerink, J.E.E. (2008). Die Toepassing Van Bedryfs-En Bestuursrekeningkunde Vir Die Ontwikkeling Van Kleinsakeondernemings In Suid-Afrika [The Application Of Cost And Management Accounting For The Development Of Small Business Enterprises In South Africa.] Unpublished Ph.D thesis.

Vanderbijlpark: North-West University. 